dr hab. Jan FAZLAGIĆ, prof. UEP

Wydział Zarządzania, Uniwersytet Ekonomiczny w Poznaniu

e-mail: jan.fazlagic@ue.poznan.pl

DOI: $10.15290 /$ ose.2017.01.85.04

\title{
EDUKACJA NA RZECZ ROZWOJU KREATYWNOŚCI JAKO CZYNNIK PROROZWOJOWY
}

\begin{abstract}
Streszczenie
W artykule przedstawiono problematykę obejmującą związki pomiędzy edukacją na rzecz rozwoju kreatywności a innowacyjnością i wzrostem gospodarczym. Opracowanie łączy w sobie trzy perspektywy poznawcze: pedagogiczną (edukacja), psychologiczna (kreatywność) oraz ekonomiczną (innowacyjność, wzrost gospodarczy). Edukację na rzecz kreatywności zaprezentowano jako jeden z możliwych sposobów pobudzenia wzrostu gospodarczego. Autor zwrócił uwagę na fakt, że związki przyczynowo-skutkowe w gospodarce pomiędzy nakładami na innowacje a wynikami w obszarze innowacji powinny być rozszerzone o kwestie związane z nakładami na edukację w obszarze kreatywności. W opracowaniu opisano wyniki badań dotyczących znaczenia kreatywności w programach nauczania krajów Unii Europejskiej. Jest to jeden z możliwych do zastosowania mierników nakładów proinnowacyjnych w gospodarce, którego w aktualnie stosowanych statystykach innowacyjności nie zauważa się bądź nie uznaje się go za istotny. Edukacja dla kreatywności przestała więc być jedynie obszarem zainteresowań psychologów i pedagogów, a zdaniem autora, powinna stać się priorytetem strategicznym polityki publicznej. Postulaty, argumenty i wyniki badań, które znalazły się w niniejszym artykule, posłużyły poparciu tej tezy.
\end{abstract}

Słowa kluczowe: kreatywność, edukacja, systemy edukacji, innowacje

\section{EDUCATION FOR CREATIVITY DEVELOPMENT AS ENABLER OF ECONOMIC GROWTH}

\begin{abstract}
Summary
The paper discusses the interrelationships between education focused on creativity and innovation as well as economic growth. The author takes into account the following cognitive perspectives: the pedagogy perspective (education), the psychology perspective (creativity), and the economics perspective (economic growth and innovation). Education for creativity is presented as one of the possible ways of stimulating economic growth. The author emphasizes that the cause-effect relationships between inputs and outputs of innovation in the economy should take education for creativity into consideration. The research findings regarding the importance of creativity in the curricula of the education systems in EU countries are presented in order to illustrate the main points of the discussion. The focus on creativity in curricula is a potential new area of measurement of innovation inputs, an approach which is
\end{abstract}


currently neglected or underestimated. Education for creativity development has gone beyond the research focus of psychology and pedagogy and, according to the author, should become a strategic priority in the economic agenda of modern public policies. The postulates, arguments and research findings presented in this paper are aimed to support this statement.

Key words: creativity, education, education systems, innovations

JEL: I21, I29, O35

\section{Wstęp}

Kreatywność to zagadnienie, które jest obiektem badań i zainteresowań bardzo szerokiego grona badaczy: socjologów, ekonomistów, psychologów, pedagogów i innych. Co więcej, wokół tego pojęcia rozwijają się autonomiczne specjalności badawcze, takie jak: psychologia kreatywności, kreatologia czy ekonomia kreatywności. Kreatywność od niedawna staje się obiektem większego zainteresowania ekonomistów, dla których jest ona kompetencją niezbędną w odniesieniu do innowacyjności przedsiębiorstw, która z kolei pozytywnie wpływa na wzrost gospodarczy. Celem niniejszego opracowania jest przybliżenie czytelnikowi problematyki edukacji na rzecz kreatywności. W tradycyjnym modelu edukacji, jaki stworzyło Państwo Pruskie w I połowie XIX wieku, cel edukacji był jednoznaczny i oczywisty: szkoła miała służyć wykształceniu przyszłych rekrutów. Znane jest powiedzenie charakteryzujące państwo pruskie jako „Armia z Państwem". Pod koniec XIX wieku model pruskiej edukacji został upowszechniony niemal na całym świecie i sprzyjał nie tylko budowaniu potęgi militarnej Prus, ale także budowaniu przemysłu w takich państwach, jak: Wielka Brytania, II Rzesza Niemiecka, Stany Zjednoczone, Francja, Belgia i inne. Można więc odnaleźć pewne paralele pomiędzy sytuacją systemów edukacji na początku XIX i na początku XXI wieku. W obu przypadkach systemy edukacji miały przyczynić się do rozwiązania pewnego problemu rozwojowego związanego z państwem. Kiedyś było nim zbudowanie skutecznej armii opartej na poborze powszechnym, a obecnie jest nim stworzenie kreatywnego społeczeństwa, które będzie zdolne uczestniczyć w globalnym wyścigu (który już trwa) na polu innowacji. Edukacja dla kreatywności przestała więc być jedynie obszarem zainteresowań psychologów i pedagogów, a zdaniem autora, powinna stać się priorytetem strategicznym polityki państwowej. Prezentowane w niniejszym opracowaniu tezy, argumenty i wyniki badań posłużyły poparciu tej tezy.

\section{Istota kreatywności}

Kreatywność jest zdolnością do tworzenia nowych rozwiązań. National Advisory Committee on Creative and Cultural Education (NACCCE) opisuje cztery następujące cechy kreatywności:

- kreatywność wymaga wykorzystania wyobraźni; 
- $\quad$ kreatywne działanie jest działaniem celowym, które wiąże się z osiagnięciem rezultatu;

- $\quad$ rezultatem kreatywnego działania jest oryginalne dzieło;

- efekt powinien być wartościowy pod względem założonych celów [Lloyd, Smith, 2004].

Kreatywność (twórczość) to proces prowadzący do nowego wytworu, który jest akceptowany jako użyteczny do przyjęcia dla pewnej grupy w pewnym okresie [Nęcka, 2003, s. 17]. Myślenie kreatywne to myślenie, którego wynikiem są oryginalne i dające się zastosować rozwiązania. Kreatywność, według Anny Murdoch, to działanie, robienie czegos zwyczajnego w niezwylety sposób [Murdoch, 2005, s. 82]. Sprawny system edukacji w XIX i XX wieku miał za zadanie dostarczenie państwu i pracodawcom posłusznych, zdyscyplinowanych żołnierzy i robotników. W XXI wieku priorytety zmieniły się. Kreatywność, która kiedyś była utożsamiana ze światem artystów i sztuki, a więc z dyscypliną niszowa, stojącą niejako na uboczu głównych priorytetów edukacji, dzisiaj staje się jej głównym priorytetem. Pojawia się więc kwestia wdrożenia edukacji sprzyjającej rozwojowi kreatywności w powszechnych systemach edukacji.

Psychologowie akcentują konieczność współistnienia dwóch komponentów, aby dane dzieło nazwać dziełem twórczym. Sa nimi oryginalność, czyli statystyczna rzadkość występowania danego rozwiązania oraz funkcjonalność, czyli przydatność danego dzieła [http://www.apa.org/monitor/nov03/creativity.aspx, data wejścia: 10.10.2016]. Dużym wyzwaniem zarówno dla badaczy kreatywności, jak i dla tych, którzy chcą ja rozwijać u innych (np. nauczycieli), jest fakt, że kreatywność występuje pod wieloma postaciami i w wielu formach. Znacznie trudniej ją „opomiarować”, co może ilustrować porównanie wybitnego utworu muzycznego z odkryciem w zakresie chemii organicznej. W amerykańskim urzędzie patentowym stosuje się jeszcze jedno kryterium: jest nim brak oczywistego połączenia nowej idei z czymś, co obecnie istnieje [http://www.apa.org/monitor/nov03/creativity.aspx, data wejścia: 10.10.2016]. Inną ważną cechą kreatywności jest istnienie niejako dwóch równoległych wymiarów, które psychologowie nazywają kreatywnością typu „C” (pisane wielką litera) oraz typu „„”. Ta pierwsza dotyczy twórczości dziecięcej, niedojrzałej. Problem z perspektywy systemu edukacji polega na tym, że atrybuty kreatywności „„” nie są dobrymi predykatorami przyszłej kreatywności typu „C’. Innymi słowy, kreatywny uczeń w szkole niekoniecznie stanie się wynalazca, wybitnym kompozytorem czy innowatorem społecznym. W kreatywności liczy się także postawa wobec (przyszłego) dzieła. Wysoki poziom motywacji sprawia, że kreatywne osoby uzyskują osiagane cele ${ }^{1}$.

\section{Kreatywność w programach nauczania}

Firma IBM przeprowadziła badanie wśród 1500 prezesów firm z 60 krajów, z którego wynikało, że najważniejsze dla sukcesu w biznesie nie są dyscyplina i rygorystyczna

${ }^{1}$ Radykalne teorie kreatywności opierają się na twierdzeniu, że wybitne osiagnięcia kreatywne sa wynikiem wytrwałości twórców, a nie ich wyjątkowego „talentu”. Wiąże się z tym m.in. tzw. Teoria 10 tys. godżin spopularyzowana przez Malcolma Gladwella [2007]. 
realizacja strategii, ale właśnie kreatywność [Andrew, 2014]. W edukacji ważne jest kształtowanie pożądanych postaw i umiejętności, które następnie mogą być wykorzystane na pożytek społeczeństwa. Szkoła musi nauczać takich umiejętności, które będą uniwersalne i przydadzą się uczniom bez względu na wykonywany później zawód. Niewątpliwie, do takich umiejętności należy umiejętność kreatywnego myślenia, a także umiejętność pracy w zespole (ze szczególnym naciskiem na umiejętność wykorzystania kreatywności jego członków). Istnieje coraz więcej dowodów na znaczenie kreatywności jako czynnika, który z jednej strony jest niedoceniany w programach nauczania, a z drugiej uznawany za kluczowy w osiaganiu celów życiowych przez jednostkę.

Najczęściej kreatywność jest kojarzona z kreatywnym myśleniem lub kreatywnym rozwiązywaniem problemów. Jeśli chodzi o zdolność do kreatywnego rozwiązywania problemów, to od jakiegoś czasu sa prowadzone przez organizację OECD badania porównawcze zdolności uczniów w ramach Programu Międzynarodowej Oceny Umiejętności Uczniów (PISA)2. Jednym z obszarów badawczych jest właściwa zdolność do rozwiązywania problemów. Badaniem, którego wyniki opublikowano w 2014 roku, objęto 44 kraje [http://www.szwecjadzisiaj.pl/kreatywne-rozwiazywanie-problemowszwedzi-ponizej-sredniej-pisa/, data wejścia: 27.10.2015]. Najnowszy raport świadczy o tym, że najlepiej z kreatywnym rozwiazywaniem problemów radzą sobie uczniowie w: Singapurze (562 punkty), Korei Południowej (561) i Japonii (552). Następni są Chińczycy, co wyraźnie dowodzi, że pod tym względem kraje azjatyckie są bezkonkurencyjne. Z kolei, najniżej w rankingu znajdują się takie kraje, jak: Kosowo, Liban, Peru, Albania, Algieria [http://prishtinainsight.com/kosovos-education-systemamongst-worst-world/, data wejścia: 10.10.2016].

Oprócz najbardziej popularnych, prowadzonych na największą skale badań PISA, mają miejsce różnego rodzaju badania porównawcze dotyczące systemów edukacji w różnych krajach, w tym także programów nauczania. Niemieccy badacze, Gregor Heilmann i Werner B. Korte, dokonali kompleksowej analizy treści programów nauczania w krajach Unii Europejskiej, w szkołach podstawowych i średnich. Zbadano częstotliwość występowania słów takich, jak 'kreatywność, 'innowacyjność' oraz ich synonimów (patrz: tabela 1. i schemat 1.). Wyniki nie były oczywiste. W krajach najbardziej rozwiniętych gospodarczo i innowacyjnych, takich jak Szwecja, wcale nie zaobserwowano podwyższonego eksponowania analizowanych słów w programach nauczania. Równocześnie jednak kraje o niskiej innowacyjności nie wypadły dobrze. Polska znalazła się w skrajnej, prawej kolumnie, a więc grupującej kraje o najmniejszej częstotliwości występowania słowa 'kreatywność'.

W analizowanych programach nauczania słowo 'kreatywność' najczęściej pojawiało się w takich przedmiotach nauczania, jak muzyka czy plastyka, choć w niektórych krajach słowa związane z kreatywnością dotyczyły wszystkich przedmiotów (szczególnie w Irlandii Północnej i Szkocji). W innych krajach, jak wcześniej zauważono, to słowo prawie

2 Badanie Programu Międzynarodowej Oceny Uczniów (Programme for International Student Assessment - PISA) to najważniejsze i największe badanie edukacyjne na świecie. Sprawdza ono stopień przygotowania piętnastolatków do dalszej edukacji, wymagań rynku pracy i powodzenia w dorosłym życiu. Przeprowadza się je cyklicznie, co trzy lata, począwszy od 2000 roku. 
nigdy nie pojawiło się (wśród tych krajów znalazły się: Polska, obok Dolnej Saksonii, Danii, Francji, Holandii).

TABELA 1.

Częstotliwość występowania słowa 'kreatywność' w programach nauczania krajów UE-27 (w 2010 roku)

\begin{tabular}{|c|c|c|}
\hline $\begin{array}{l}\text { Wysoka (przeciętne wy- } \\
\text { stępowanie }>1,0 \text { ) }\end{array}$ & $\begin{array}{l}\text { Srednia (przeciętne wy- } \\
\text { stępowanie }>0,5-<1 \text { ) }\end{array}$ & $\begin{array}{c}\text { Niska (przeciętne wystę- } \\
\text { powanie }<0,5 \text { ) }\end{array}$ \\
\hline $\begin{array}{c}\text { Austria } \\
\text { Belgia - społeczność nie- } \\
\text { mieckojęzyczna } \\
\text { Czechy } \\
\text { Estonia } \\
\text { Węgry } \\
\text { Litwa } \\
\text { Lotwa } \\
\text { Portugalia } \\
\text { Słowenia } \\
\text { Zjednoczone Królestwo - } \\
\text { Irlandia Północna } \\
\text { Zjednoczone Królestwo - } \\
\text { Szkocja }\end{array}$ & $\begin{array}{c}\text { Belgia - Flandria } \\
\text { Bulgaria } \\
\text { Niemcy - Bawaria } \\
\text { Niemcy - Saksonia } \\
\text { Grecja } \\
\text { Hiszpania - Andaluzja } \\
\text { Hiszpania - Estremadura } \\
\text { Hiszpania - Madryt } \\
\text { Hiszpania - poziom naro- } \\
\text { dowy } \\
\text { Finlandia } \\
\text { Francja } \\
\text { Irlandia } \\
\text { Luksemburg } \\
\text { Słowacja } \\
\text { Szwecja } \\
\text { Anglia } \\
\text { Zjednoczone Królestwo - } \\
\text { Zjednoczone Królestwo - } \\
\text { Walia }\end{array}$ & $\begin{array}{c}\text { Belgia - Walonia } \\
\text { Niemcy - dolna Saksonia } \\
\text { Dania } \\
\text { Włochy } \\
\text { Malta } \\
\text { Holandia } \\
\text { Polska } \\
\text { Rumunia }\end{array}$ \\
\hline
\end{tabular}

Źródło: [Heilmann, Korte, 2010].

Na uwagę zasługuje wysoki wynik uzyskany przez Wielką Brytanię, co nie powinno dziwić, zważywszy na wysokie miejsca w rankingach międzynarodowych zajmowane przez gospodarkę brytyjską, a także niekwestionowane osiagnięcia na polu kreatywności (sektory kreatywne w Wielkiej Brytanii stanowią jeden z jej ważnych filarów wzrostu). Jednocześnie można zaobserwować wysoki wynik Estonii. Bliska kulturowo Estonii, a jednocześnie jedna z najbardziej innowacyjnych gospodarek na świecie, Finlandia zajęła z kolei miejsce poniżej średniej. Natomiast Polska uplasowała się na jednym z najniższych miejsc, ale słaby wynik uzyskała również bardzo dobrze rozwinięta gospodarczo Holandia. W przypadku niektórych krajów (np.: Polska, Holandia) niewielki związek pomiędzy ich sytuacją gospodarczą a wynikami zajmowanym w badaniu trudno wytłumaczyć. Z drugiej strony o rzeczywistej wartości wyjaśniającej to badania będzie można przekonać się za około 25 lat, gdy absolwenci szkół trafią na rynek pracy i będą współtworzyć PKB w swoich krajach. 
SCHEMAT 1.

Relatywna częstość występowania słów: 'kreatywność', 'innowacyjność' i ich synonimów w programach nauczania krajów UE-27

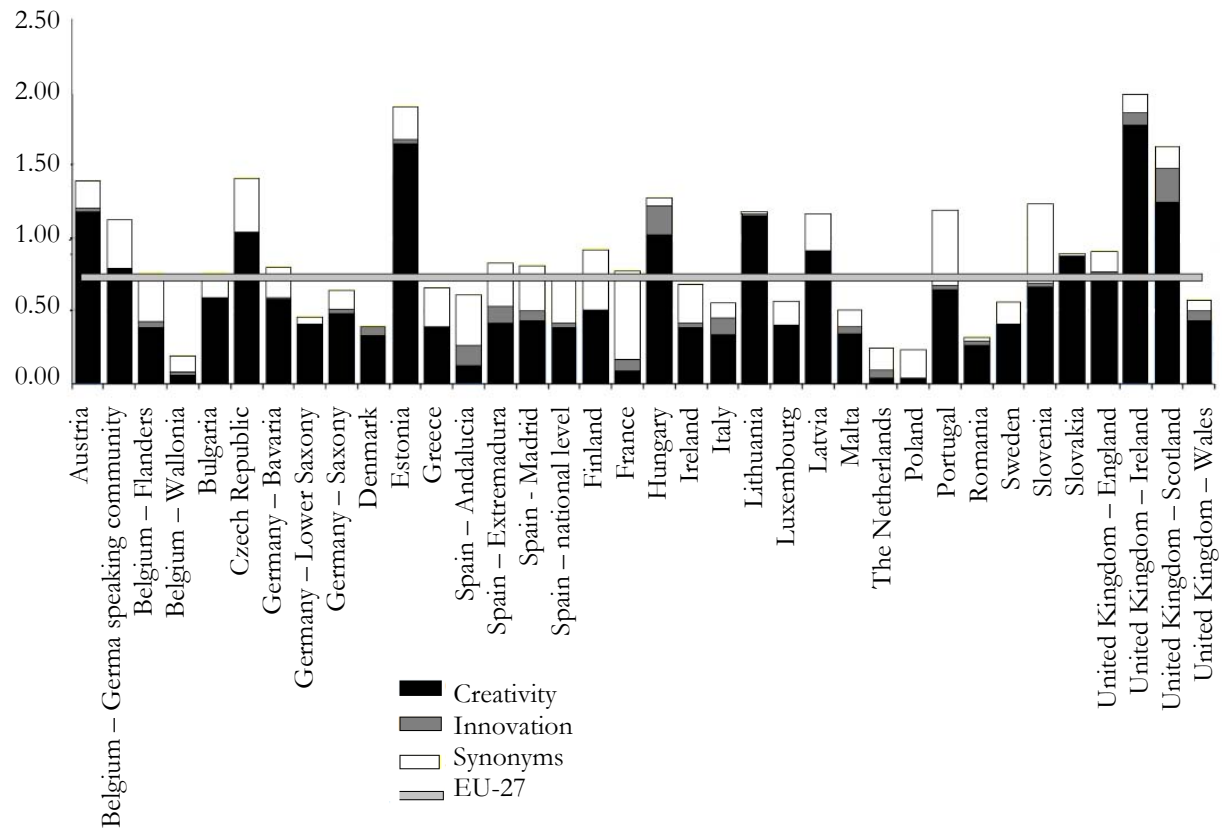

Źródło: [Heilmann, Korte, 2010, s. viii].

Kreatywność to zdecydowanie najbardziej dominujące słowo z częstością występowania zawierającą się pomiędzy 0,04 dla Holandii i Polski ${ }^{3}$ oraz 1,78 dla Irlandii Północnej. Istnieje tylko kilka wyjątków (Andaluzja, Holandia i Polska), gdzie synonimy sa częściej używane niż sam termin kreatywność. Słowo 'innowacja' jest mało popularne, z wyjątkiem Szkocji i Węgier, ale nawet w tych dwóch krajach częstość występowania wynosi od około 0,20 do 0,23 . Interesujące wyniki przedstawia tabela 2 ., na podstawie której można zauważyć relatywną częstość występowania słów związanych z kreatywnością ze względu na przedmiot nauczania.

${ }^{3} \mathrm{~W}$ przypadku Polski analizowano programy szkół: podstawowych, gimnazjalnych i ponadgimnazjalnych. 
TABELA 2.

Częstotliwość występowania słów związanych z kreatywnością ze względu na przedmioty w programach nauczania krajów UE-27 (w 2010 roku)

\begin{tabular}{|l|c|c|c|c|}
\hline \multicolumn{1}{|c|}{$\begin{array}{c}\text { Grupa przed- } \\
\text { miotów }\end{array}$} & $\begin{array}{c}\text { Występowa- } \\
\text { nie KREA- } \\
\text { TYWNOŚ- } \\
\text { CI (1) }\end{array}$ & $\begin{array}{c}\text { Występowa- } \\
\text { nie INNO- } \\
\text { WACJI (2) }\end{array}$ & $\begin{array}{c}\text { Występowa- } \\
\text { nie wszyst- } \\
\text { kich synoni- } \\
\text { mów (3) }\end{array}$ & $\begin{array}{c}\text { Wszystkie } \\
\text { terminy (1) + } \\
\mathbf{( 2 )}+\mathbf{( 3 )}\end{array}$ \\
\hline Sztuka & 1,66 & 0,03 & 0,55 & $\mathbf{2 , 2 4}$ \\
Teleinformatyka & 0,85 & 0,16 & 0,13 & $\mathbf{1 , 1 3}$ \\
Edukacja frzyczna & 0,54 & 0,01 & 0,23 & $\mathbf{1 , 1 3}$ \\
Języki & 0,50 & 0,01 & 0,15 & $\mathbf{0 , 7 8}$ \\
Nauki społeczne & 0,24 & 0,05 & 0,10 & $\mathbf{0 , 6 6}$ \\
Inne & 0,28 & 0,02 & 0,06 & $\mathbf{0 , 3 5}$ \\
Matematyka & 0,17 & 0,01 & 0,10 & $\mathbf{0 , 2 8}$ \\
Nauki przyrodnicze & 0,20 & 0,02 & 0,06 & $\mathbf{0 , 2 8}$ \\
\hline
\end{tabular}

Źródło: [Heilmann, Korte, 2010, s. xi].

Kreatywność łączy się z wieloma innymi umiejętnościami. Można stwierdzić, że kreatywność tworzy ciagg kompetencji z nią powiązanych i z nią współwystępujących. $\mathrm{Na}$ przykład wytrwałość jest sama w sobie wartościową cechą człowieka, lecz wraz z kreatywnością (nie wszyscy wytrwali ludzie są kreatywni!) pozwala na uzyskanie silnego efektu synergii. Stąd, oprócz kreatywności, należy w programach nauczania rozwijać inne cechy charakteru i kompetencji, które będą ją wspierać, np.: samodzielność, zdolność rozwiązywania problemów [Heilmann, Korte, 2010, s. xi], samo-ekspresję, ogólny rozwój osobisty. W programach nauczania z kreatywnością kojarzy się następujące słowa (ko-lokatory):

- świadomość,

- zdolność,

- niezależność,

- inicjatywa,

- uczenie się,

- osobowość,

- odpowiedzialność,

- umiejętności,

- rozwiązania,

- zrozumienie,

- myślenie,

- aktywizacja,

- inicjatywa,

- komunikacja,

- projektowanie,

- zachęcanie, 
- eksperymentowanie,

- wyjaśnianie,

- uczenie się,

- pisanie (tekstów),

- praca

- $\quad$ zrozumienie.

W przypadku niektórych z wyżej wymienionych słów związek z kreatywnością może wydawać się nieoczywisty, lecz, zdaniem autorów badania, łączą się one z kreatywnościa, ponieważ wyrażaja postawy i zachowania charakteryzujące: kreatywny produkt (efekt pracy kreatywnej), kreatywny proces, kreatywną osobowość itp. ${ }^{4}$

Niski priorytet związany z kreatywnością w nauczaniu nie jest jedynie polską bolączką. W Wielkiej Brytanii sytuacja w tym obszarze była podobna jak w Polsce. Komitet do spraw Edukacji Parlamentu Brytyjskiego wydał oświadczenie, w którym stwierdzono: Szkoly odnoszqce sukcesy to także kreatywne sqkoly [http:/ / news.bbc.co.uk/ 2/hi/uk_news/education/7069614.stm, data wejścia: 05.10.2015]. Zgodnie z doświadczeniami brytyjskimi, wsparcie dla kreatywności w szkole rozpoczyna się na poziomie programów nauczania. Poświęcenie większej uwagi kreatywności wspomaga rozwój zdolności dzieci, a więc nie można stwierdzić, że zwiększenie priorytetu wobec tego obszaru umniejsza rolę innych priorytetów w edukacji. Dzięki badaniom brytyjskim wiadomo na przykład, że uczniowie, którzy współpracowali z kreatywnymi nauczycielami i mentorami, na przykład pisarzami czy projektantami mody, stawali się bardziej punktualni i podnosili ogólny poziom innych zdolności, takich jak: zdolność do improwizacji, chęć podejmowania ryzyka, wytrwałość i zdolność współpracy. Z badań, przeprowadzonych w 2009 roku na próbie 10 tys. nauczycieli ze wszystkich krajów EU-27 zleconych z okazji międzynarodowego roku kreatywności, wynika, że:

- $\quad$ zdecydowana większość nauczycieli jest przekonana, że kreatywność można zastosować w każdej dziedzinie nauczania oraz że każdy może być kreatywny. Respondenci także zgadzają się z tym, iż kreatywność to podstawowa umiejętność, jakiej należy uczyć w szkole (mimo że nie mają pewności co do tego, jak jej nauczać);

- $\quad$ średnio rzecz ujmując, 4 na 10 nauczycieli otrzymało pewne formy wsparcia zawodowego w zakresie nauczania kreatywności, lecz różnice pomiędzy poszczególnymi krajami EU-27 są znaczne. Na Słowacji jest to $66 \%$, ale zaledwie 14\% we Francji, 25\% na Litwie, 27\% na Wegrzech oraz 28\% w Wielkiej Brytanii i 33\% w Hiszpanii [Cachia, Ferrari, 2010].

$\mathrm{Na}$ schemacie 2. przedstawiono odsetek nauczycieli, którzy zostali przeszkoleni w zakresie kreatywności. Niski wynik Francji (14\%) może zastanawiać, biorąc pod uwagę wysoki poziom innowacyjności tej gospodarki, jak również tradycyjna, wielowiekową historię spektakularnych osiagnięć na wielu polach aktywności, które były dziełem Francuzów. Być może w stosunku do tego kraju „nośnikiem” kreatywności jest sama kultura narodowa i w związku z tym nauczyciele nie muszą być specjalnie „,szko-

${ }^{4}$ Więcej na ten temat m.in. w: [Ivcevich, 2009, s. 17-21; Mooney, 1963, s. 331-340]. 
leni’. Podobna sytuacja ma miejsce w przypadku Węgier (27\%), które również z historycznego punktu widzenia wydały na świat wielu wybitnych twórców, w tym Noblistów. Najwyższe wyniki zanotowano w trzech krajach byłego Bloku Wschodniego, takich jak: Słowacja, Estonia i Rumunia. Polski wynik (40\%) znalazł się w przedziale najczęściej występujących wyników wśród badanych krajów.

SCHEMAT 2.

Odsetek nauczycieli, którzy zgadzają się z opinią: „W czasie mojej edukacji nauczycielskiej poruszano kwestie związane z kreatywnością”

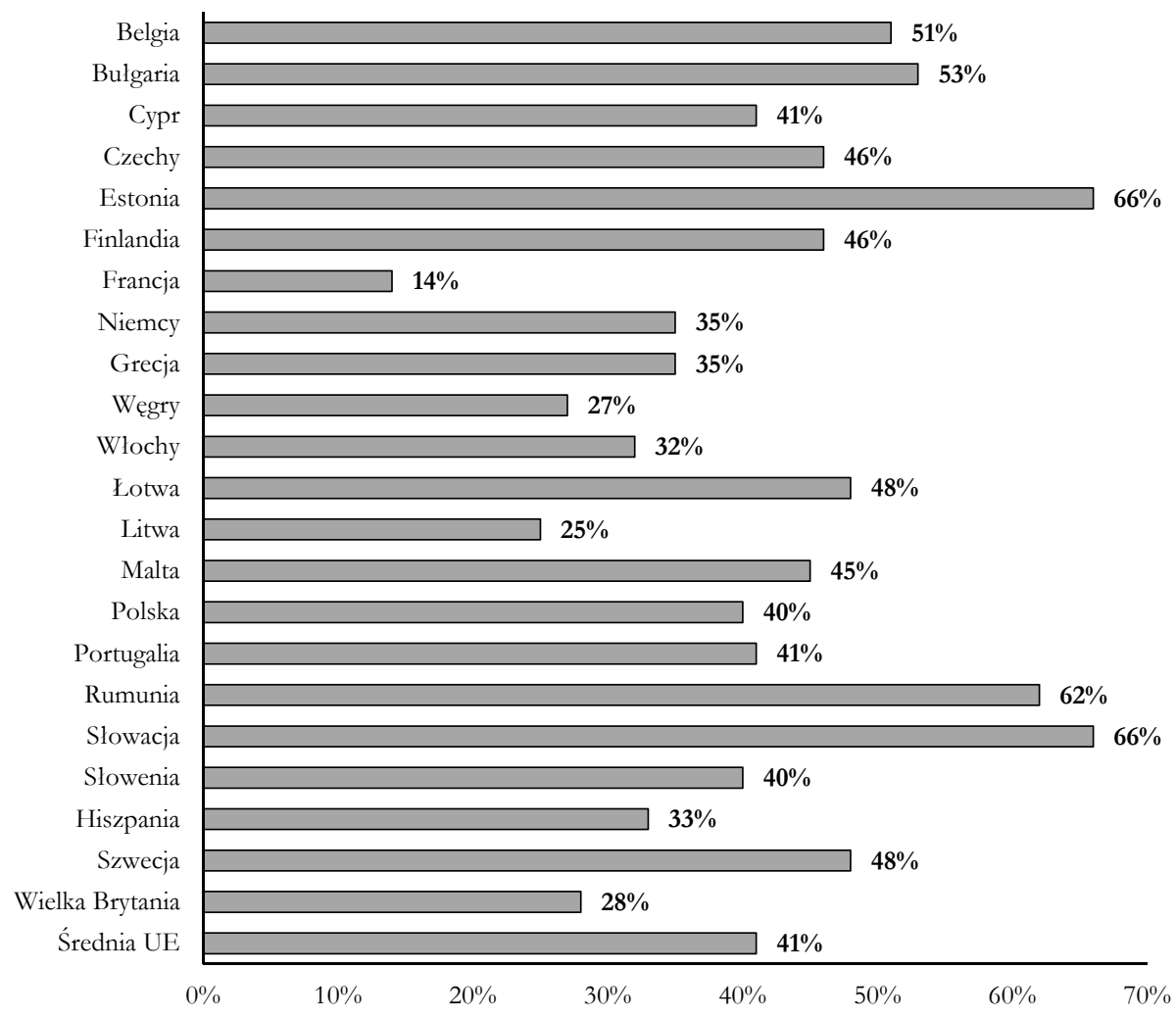

Źródło: [Cachia, Ferrari, 2010, s. 19].

Celem porównania, warto spojrzeć na rozkład odpowiedzi dotyczących kwestii wykorzystania technologii informatycznych przez nauczycieli w klasie (schemat 3.). Analogicznie jak w poprzednim pytaniu, najwyższe wyniki (60\% i więcej) uzyskały trzy kraje byłego Bloku Wschodniego, a mianowicie: Słowacja, Łotwa i Rumunia. Jednak może to świadczyć o ogólnym niskim poziomie kompetencji informatycznych wśród nauczycieli w tych krajach i de facto być wskaźnikiem o zabarwieniu negatywnym, i na odwrót, 
niskie poziomy wskazań w innych krajach (np. w Niemczech) moga pozytywnie świadczyć o kompetencjach informatycznych wśród nauczycieli tych krajów.

SCHEMAT 3.

Odsetek nauczycieli, którzy zgadzają się z opinią: „W czasie mojej edukacji nauczycielskiej uczono mnie, jak wykorzystywać technologie informatyczne w klasie"

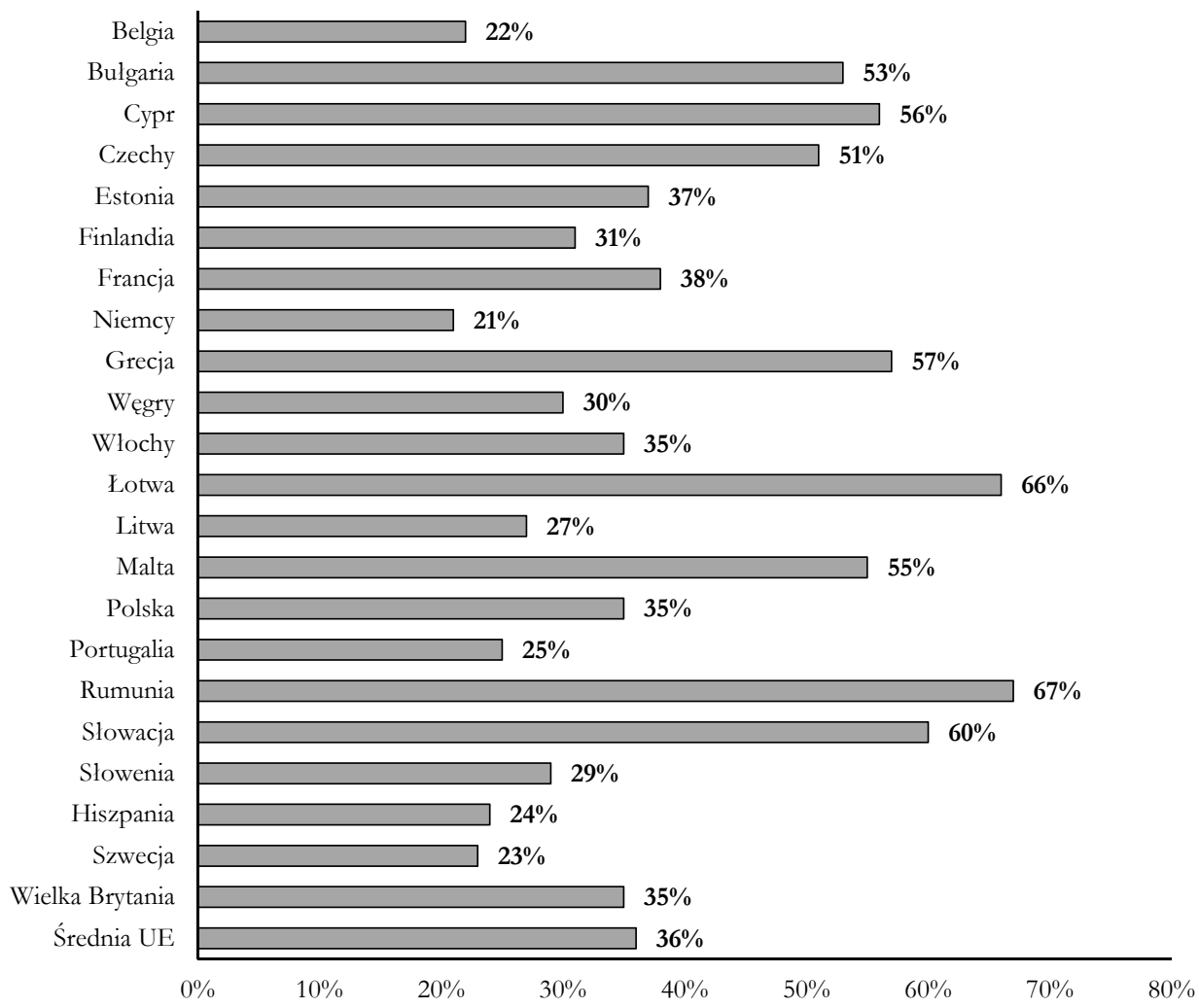

Źródło: [Cachia, Ferrari, 2010, s. 23].

\section{Sposoby promowania kreatywności w szkołach}

Kreatywność jest niezwykle praktyczną zdolnością, ale pomimo to jest traktowana, szczególnie w Polsce, bez należytej uwagi i troski, czego dowodzą przedstawione powyżej wyniki badań. Nawet, jeśli mamy do czynienia z werbalną deklaracją np.: „Szkoła uczniów kreatywnych”, „Kreatywne przedszkole” itp., to nie oznacza automatycznie, że w takim miejscu stosuje się edukację sprzyjającą rozwojowi kreatywno- 
ści. Na niekorzyść współczesnej szkoły świadczą nie tylko wyniki analizy treści programów nauczania. Sama ocena uczniów związana z kreatywnością jest także ważnym miernikiem. W Stanach Zjednoczonych 95\% uczniów szkół drugiej klasy szkoły podstawowej uważa, że jest kreatywny, ale już tylko 5\% uczniów ostatniej klasy szkoły średniej jest tego samego zdania [Westby, Dawson, 1995, s. 1-10].

W szkołach uczy się zwykle zbyt duża liczba uczniów, stąd są ograniczone przez biurokrację. Ogromna liczba „klientów” szkoły wymusza: biurokrację, porządek, procedury i dużą dozę dyscypliny. Przez ostatnie sto lat treści nauczania na pewno zmieniły się, jednak idea szkoły restrykcyjnej, dyscyplinującej, ograniczającej „psychicznego więzienia" ma się dobrze. Uczniowie i nauczyciele, którym bardziej odpowiada taki system społeczny, z natury będą sobie lepiej radzili w szkole. Podział na przedmioty w szkole, który zabija kreatywność, nie jest tylko dominująca cechą polskiej szkoły http://www.ascd.org/publications/educational-leadership/feb13/vol70/num05/ Learning-from-Creative-Teachers.aspx, data wejścia: 03.06.2016]. Daniel Pink uważa, że kreatywne myślenie staje się coraz ważniejszą kompetencją we współczesnym świecie, niezbędną do realizacji celów [Pink, 2005]. Kreatywne osoby mają zdolność do rozwijania gruntownej wiedzy specjalistycznej w obszarze, który jest ich domena zawodowa, ale jednocześnie nie traca zdolności do widzenia świata poza swoją dziedziną [Pink, 2005]. Warto zastanowić się, jak tę zasadę wdrażają w życie dobrzy nauczyciele? Amerykańscy badacze przeprowadzili wywiady z nauczycielami, którzy uzyskiwali najwyższe wyróżnienia za swoją pracę zawodową w Stanach Zjednoczonych (The National Teacher of the Year Award). Odkryto, że 90\% finalistów konkursu i zwycięzców uznało kreatywność w swojej pracy za najważniejszy czynnik decydujący o ich sukcesie. Ponadto, z tych badań wynikł interesujący wniosek, a mianowicie:

\section{Efektywne nauczanie = kreatywne nauczanie.}

Badacze odkryli także pięć kluczowych postaw najlepszych nauczycieli, którzy wdrażali tę zasadę w życie. Przedstawiono je poniżej.

1. Lączenie własnych zainteresowań nauczyciela z przedmiotem nauczania. Badania dowodzą, że najbardziej innowacyjni ludzie w każdej sferze są również kreatywni w obszarach wykraczających poza ich dziedzinę zawodową [Root-Bernstein, Bernstein, 1999; Root-Bernstein, 2003]. Zwycięzcy amerykańskich konkursów mieli wiele hobby i zainteresowań, pasji. Ponadto, wykorzystywali je w swojej codziennej pracy nauczyciela. Szczególnie przydatne w nauczaniu jest spożytkowanie hobby artystycznych nauczyciela. $\mathrm{Na}$ przykład jeden z nauczycieli fizyki, pasjonat grafiki i fotografii, polecił uczniom stworzenie reklam promujących różnego rodzaju koncepcje naukowe, np. plakat reklamujący chloroplasty.

2. Lączenie teorii z praktyką świata szkolnego ze światem rzeczywistym. Należy wyodrębnić wiedzę z próżni, jaką są realia klasy lekcyjnej. Pewien nauczyciel geografii rozpoczął lekcję od wyjścia na podwórko szkolne i obserwowania pogody. Później z tego pomysłu ewoluował ogólnoświatowy projekt, w którym dzieci wysyłały dane o pogodzie do naukowców w NASA. Inna nauczycielka w ramach pracy projektowej dała uczniom zadanie polegające 
na stworzeniu fikcyjnej organizacji non-profit dla defaworyzowanej grupy społecznej. Uczniowie w ramach projektu mieli za zadanie przeprowadzać wywiady z lokalnymi organizacjami pozarządowymi, a następnie konkurować w konkursie o otrzymanie grantu na swój projekt w konkursie klasowym. Komisja konkursowa składała się z członków lokalnej społeczności.

3. Dbanie o kreatywne nastawienie. Większość z nauczycieli, którzy zdobyli nagrodę w konkursie The National Teacher of the Year Award, stwierdziła, że kreatywność to nie jest jakaś abstrakcyjna kompetencja, oderwana od innych zachowań nauczyciela. Kreatywny nauczyciel ma swego rodzaju postawę lub nastawienie (mindset) do otaczającego świata. Aby je podtrzymać i rozwijać, należy mieć otwarty umysł i nie pozwalać mu zasklepić się. Tutaj najważniejsze jest samodoskonalenie ze strony nauczyciela - 10 minut dziennie na trening umysłu w zupełności wystarczy.

4. Współpraca $z$ innymi nauczycielami. Kontakty $z$ innymi nauczycielami to najpewniejszy sposób na utrzymanie otwartego umysłu i zapewnienie dopływu nowych pomysłów. Nauczyciele mają naturalną tendencję do zacieśniania współpracy z innymi nauczycielami tego samego przedmiotu. Nie jest to wystarczające. Najlepsi nauczyciele poszukują inspiracji wśród nauczycieli innych przedmiotów, np.: poloniści powinni współpracować z nauczycielami wychowania fizycznego (czyż nie łatwiej uczyć odmiany nazwisk przez przypadki na sali gimnastycznej, gdy omawia się zadania drużyny koszykówki?).

5. Podejmowanie ryzyka intelektualnego. W tym przypadku potrzebna jest odwaga, a także gotowość do ponoszenia porażek. Nauczyciel powinien zapewnić poczucie bezpieczeństwa tak, aby uczniowie byli przygotowani do podejmowania wyzwań bez obawy przed porażką. Nie ma mowy o nauczaniu kreatywności bez wprowadzenia elementu ryzyka i treningu radzenia sobie $z$ porażkami.

Z badań Herberta Simona ${ }^{5}$ przeprowadzonych wśród wybitnych szachistów wynika, że:

- $\quad$ ich sukcesy nie zależą w prostej linii od: ilorazu inteligencji, zdolności matematycznych, pamięci, wyobraźni itp., również nie są wprost proporcjonalne do stażu zawodowego (coraz więcej jest młodych, niedoświadczonych arcymistrzów, nawet 12-15-letnich);

- $\quad$ wygrywaja z komputerami, które, jak wiadomo, są w stanie wielokrotnie szybciej i głębiej przeanalizować sytuację na szachownicy;

- popełniają mniej więcej tyle samo błędów, grając z ludźmi w dwóch odmiennych sytuacjach; zarówno w rozgrywkach indywidualnych, kiedy na wykonanie ruchu jest pół godziny, jak i w rozgrywkach symultanicznych, gdy na wykonanie ruchu jest często mniej niż jedna minuta [Simon, 1998].

Tak więc, kreatywność jest cechą osobową, która ma znaczny wpływ na sprawność życiową.

${ }^{5}$ Autor był psychologiem, jednym z twórców psychologii kognitywnej, jak również laureatem Nagrody Nobla (w dziedzinie ekonomii). 


\section{Sposoby pobudzania kreatywności u uczniów}

Wielkim wyzwaniem dla systemów edukacji w XXI wieku jest przeprojektowanie starego, sięgającego swymi korzeniami do dziewiętnastowiecznych Prus, systemu edukacji. Rzecz w tym, aby nauczyciele potrafili nauczać kreatywności i kształtować szacunek dla tej kompetencji w społeczeństwie. Brytyjscy pedagodzy zalecaja poniższe działania, które mają na celu pobudzenie kreatywności u uczniów:

1. Przy planowaniu zajęć dydaktycznych uwzględnić wielość stylów uczenia się uczniów.

2. Zapewnić możliwość eksperymentowania, rozwiązywania problemów.

3. Wykorzystywać techniki kreatywnego myślenia.

4. Dawać uczniom możliwość wyboru.

5. Zadawać pytania otwarte, takie jak: „Co się stanie jeżeli...?”, „Co zrobiłbyś, jeżeli...?”.

6. Zachęcać uczniów do niezgadzania się z nauczycielem - uczyć polemiki.

7. Nauczyć uczniów doceniać oryginalność m.in. poprzez wyrobienie w nich gustu.

8. Nauczyć uczestniczenia w otwartej dyskusji.

9. Uczyć, jak wyciagać wnioski z własnych porażek [http://www.journeytoexcellence. org.uk/resourcesandcpd/research/summaries/rsfosteringcreativity.asp, data wejścia: 05.10.2015].

Nauczanie kreatywności w szkole wcale nie jest prostą sprawa. Często problem ten jest upraszczany i sprowadzany do nauczania przedmiotów artystycznych. Nie wystarczy, aby nauczyciele sporadycznie stosowali proste, czasami nieskuteczne techniki, takie jak odtwarzanie muzyki Mozarta ${ }^{6}$. Rola szkoły jest dostarczanie uczniom takich doświadczeń edukacyjnych, których sami nie są w stanie sobie zapewnić w życiu poza szkoła [http://ww2.kqed.org/mindshift/2014/03/18/can-creativity-truly-be-fostered-inclassrooms-of-today/, data wejścia: 02.10.2015]. W polskiej kulturze porażka jest kojarzona z: piętnowaniem, stygmatyzowaniem, wyśmiewaniem itp. Kiedy małe dziecko po raz pierwszy próbuje powstać z kolan i chodzić na oczach rodziców, wszyscy mu kibicuja. Gdy po chwili przewraca się i upada, wszyscy z radością klaszczą i doceniaja jego odważna, ale zakończoną porażka próbę. Dziecko odwzajemnia uśmiech i cieszy się, że sprawiło radość rodzicom. Tym samym uczy się ono, że porażka jest krokiem na drodze do sukcesu. Potem system edukacji zaczyna wpajać zupełnie inne postawy wobec porażki. W szkole dzieci zauważają że najlepiej nie odzywać się, jeżeli nie znaja odpowiedzi na pytanie zadane przez nauczyciela, gdyż jeśli odpowiedza ,,niewłaściwe”, nikt ich za to nie pochwali. W szkole nie opłaca się podejmowanie ryzyka. Świat widziany przez pryzmat szkolnych testów staje się czarno-biały: jest jedna „właściwa” odpowiedź na każde „właściwe” pytanie. Kreatywność prowadzi do problemów. W taki sposób po około 15-20 latach system edukacji wykształca pokolenie, które boi się ryzyka.

${ }^{6}$ Często muzyka Amadeusza Mozarta jest uznawana za ten rodzaj muzyki, który pobudza kreatywność. Niestety, jest to tylko mit. Z badań wynika, że muzyka ta nie ma pozytywnego wpływu na kreatywność. Więcej na ten temat w: [Lilienfeld, Lynn, Ruscio, Beyerstein, 2011]. 
Gdy ten sam człowiek po 20 latach spróbuje rozpocząć działalność gospodarcza, lecz zbankrutuje, nie może liczyć na aprobatę.

W Stanach Zjednoczonych i w Wielkiej Brytanii pojawiają się eksperymentalne programy mające na celu zmianę podejścia szkoły do kwestii porażek i uczenia się na błędach. Stowarzyszenie Nauczycieli w Kalifornii (California Teacher's Association) opublikowało tekst pt.: Nauczanie podnoszenia sie po porażce (Teaching Students to Bounce Back, Donaldson, 2014). Jedna z najlepszych w Wielkiej Brytanii szkół żeńskich - Wimbledon High School - przeprowadziła innowacyjny eksperyment edukacyjny. Nazwano go Tydzien porą̇ki (Failureweek). Jego celem było nauczenie, jak radzić sobie z ryzykiem przedsięwzięć życiowych, zwiększyć odporność psychiczną na własne porażki oraz uczyć się na błędach. Nacisk wychowawczy kładziono na afirmację podejmowania prób, czyli odwagi. Uczennice brały udział w zajęciach, podczas których dowiadywały się, że lepiej jest spróbować odważniej podejmować decyzje, niż nic nie robić, ale także niewiele osiagnąć. Nauczyciele rozpoczęli tydzień od pogawędek z uczennicami na temat tego, jak się czują, gdy ponosza porażkę. Uczennice szkoły uzyskały najwyższe wyniki egzaminów w kraju, a pomimo to, do ich programu nauczania wprowadzono zajęcia związane z postawami wobec porażek życiowych. Jest to dowodem na wysoką jakość edukacji w tej szkole, która przejawia się tym, że uczennice są przygotowywane do wyzwań, z którymi jeszcze mogły się nie zetknać w życiu codziennym, szczególnie w procesie edukacji formalnej. Zajęcia były prowadzone w formie warsztatów, zebrań i ćwiczeń aktywizujących dla dziewcząt wraz z rodzicami oraz instruktorami spoza szkoły, którzy dzielili się doświadczeniami z własnego życia.

Jak zauważył A. Lipka, ekonomiczne wspieranie twórczości (dzięki na przykład stypendiom) wyrównuje szanse rozwojowe, pomagając w wyjściu poza sferę konieczności twórczym osobom z niezamożnych rodzin oraz małym przedsiębiorstwom sektora prywatnego prowadzącym (w sposób ciaggły lub dorywczy) działalność B+R [Lipka, 2012].

\section{Podsumowanie}

W opracowaniu niniejszym zaprezentowano szereg argumentów i dowodów pochodzących z badań naukowych, które ilustrują potrzebę położenia większego nacisku na nauczanie w systemach edukacji szeroko rozumianej kreatywności. Zdaniem autora, podniesienie poziomu kreatywności uczniów w przyszłych dziesięcioleciach będzie skutkowało wymiernymi korzyściami dla gospodarki polskiej. Jest to ważne szczególnie w kontekście obaw, jakie wyrażają ekonomiści, dotyczących „ugrzęźnięcia” Polski w trajektorii wzrostu gospodarczego, zwanej „pułapka średniego dochodu”. Co prawda polska gospodarka w ostatnich 25 latach rozwijała się szybciej niż gospodarki zachodnioeuropejskie, ale znacznie wolniej niż gospodarki krajów azjatyckich i afrykańskich. Potęga świata zachodniego zaczęła powstawać około 400 lat temu, kiedy intelektualiści i przedsiębiorcy z Niderlandów, a potem Zjednoczonego Królestwa (Rewolucja Przemysłowa w Wielkiej Brytanii byłaby niemożliwa bez holenderskich 
inwestycji kapitałowych) zaczęli z szacunkiem i uwagą słuchać tego, co mają do powiedzenia naukowcy. Chiny, Indie i Arabia przeoczyły ten moment w historii i dały się zdystansować Europejczykom. Dziś, na początku XXI wieku, można zaobserwować podobne przesilenie $\mathrm{w}$ światowym układzie sił, jakie miało miejsce $\mathrm{w}$ XVIII wieku. Kraj, który będzie potęgą u schyłku XXI wieku, będzie z pewnością zawdzięczał ja zastosowaniu kreatywności do budowy potęgi gospodarczej, ludnościowej i militarnej7. Zdecydowana większość właścicieli firm i pracowników najemnych musi pogodzić się z faktem, że zmiany w otoczeniu są tak szybkie, że stabilność zatrudnienia i dochodów przejdzie lub już przeszła do historii. Jedyną nadzieją na to, że nasza przyszłość będzie lepsza, jest wiara w to, że nadal będzie wykorzystywany zasób, jakim każdy człowiek jest obdarzony (choć w różnym nasileniu). Jest nim kreatywność.

\section{Literatura}

Ball P., 2007, Masa Krytycz̨na, Wydawnictwo Insignis, Kraków.

Cachia R., Ferrari A., 2010, Creativity in Schools in Europe: A survey of Teachers, JRC, http://ftp.jrc.es/EURdoc/JRC59232.pdf (data wejścia: 12.07.2016).

http://news.bbc.co.uk/2/hi/uk_news/education/7069614.stm (data wejścia: 05.10.2015). http://prishtinainsight.com/kosovos-education-system-amongst-worst-world/

(data wejścia: 10.10.2016]).

http://ww2.kqed.org/mindshift/2014/03/18/can-creativity-truly-be-fostered-in-

classrooms-of-today/ (data wejścia: 02.10.2015).

http://www.apa.org/monitor/nov03/creativity.aspx (data wejścia: 10.10.2016).

http://www.ascd.org/publications/educational-leadership/feb13/vol70/num05/

Learning-from-Creative-Teachers.aspx (data wejścia: 03.01.2016).

http://www.journeytoexcellence.org.uk/resourcesandcpd/research/summaries/rsf

osteringcreativity.asp (data wejścia: 05.10.2015).

http://www.szwecjadzisiaj.pl/kreatywne-rozwiazywanie-problemow-szwedzi-ponizej-

sredniej-pisa/ (data wejścia: 27.10.2015).

http://www.theguardian.com/media-network/media-network-blog/2014/jan/17/3-

myths-creativity-in-business (data wejścia: 12.07.2015).

Ekonomia kreatywności. Jakość kapitatu ludzkiego jako stymulator wrrostu społeczno-gospodarczego, 2012, A. Lipka, S. Waszczak (red.), Wydawnictwo Uniwersytetu Ekonomicznego w Katowicach, Katowice.

\footnotetext{
${ }^{7} \mathrm{Na}$ znaczenie tych trzech czynników jako determinant ogólnej siły danego państwa wskazuje m.in. Philips Ball [2007]. Kreatywność w obszarze tworzenia potęgi militarnej niekoniecznie musi być utożsamiana z destrukcja przeciwnika. Wręcz przeciwnie, może służyć zapobieganiu konfliktowi zbrojnemu dzięki np.: dobrze opracowanym strategiom obronnym, inteligentnym broniom i doktrynom. Można tu przywołać np. doktrynę fleet-in-being Admiralicji Brytyjskiej, która zakłada, że dostatecznie silna flota przez samo swoje istnienie może zniechęcić przeciwnika do konfrontacji.
} 
Heilmann G., Korte W. B., 2010, The Role of Creativity and Innovation in School Curricula in the EU27. A content analysis of curricula documents, European Commission Joint Research Centre Institute for Prospective Technological Studies, Seville.

Ivcevich Z., 2009, Creativity Map: Toward the Next Generation of Theories of Creativity, "Psychology of Aesthetics, Creativity, and the Arts", vol. 3, no. 1.

Lilienfeld S. O., Lynn S. J., Ruscio J., Beyerstein B. L., 2011, 50 wielkich mitów psychologii popularnej, Wydawnictwo CiS, Warszawa.

Lipka A., 2002 , Ekonomia kreatywności - zpogranicza kreatologii i ekonomii, [w:] Ekonomia kreatywności. Jakość kapitatu ludzkiego jako stymulator wzrostu społeczno-gospodarczego, A. Lipka, S. Waszczak (red.), Wydawnictwo Uniwersytetu Ekonomicznego w Katowicach, Katowice.

Lloyd K., Smith P., 2004, Developing Creativity for Learning in the Primary School. A Practical Guide For School Leaders, National College For School Leadership, Nottingham.

Mooney L. R., 1963, A. Conceptual Model for Integrating Four Approaches to the Identification of Creative Talent, [in:] Scientific creativity: Its recognition and Development, C.W. Taylor, F. Barron (eds.), Wiley and Sons, New York.

Murdoch A., 2005, Kreatywność w reklamie, Wydawnictwo Naukowe PWN, Warszawa. Nęcka E., 2003, Psychologia twórczości, Gdańskie Wydawnictwo Psychologiczne, Gdańsk. Pink D. H., 2005, A whole new mind, Riverhead Books, New York.

Root-Bernstein R. S., 2003, The art of innovation: Polymaths and the universality of the creative process, [in:] International handbook of innovation, L. Shavanina (ed.), Elsevier, Amsterdam.

Root-Bernstein R. S., Bernstein M., 1999, Sparks of genius: The thirteen thinking tools of the world's most creative people, Houghton Mifflin, New York.

Simon H.A., 1998, Podejmowanie decyzji menedizerskich: rola intuicji i emocji, [w:] Intuicja worganizacji. Jak twórczo przewodzić i zarzadzać?, W.H. Agor (red.), Wydawnictwo Profesjonalnej Szkoły Biznesu, Kraków.

Stownik jezyka polskiego, 2013, Wydawnictwo Naukowe PWN, Warszawa.

Westby E. L., Dawson V. L., 1995, Creativity: Asset or Burden in the Classroom?, "Creativity Research Journal", vol. 8, no. 1. 